\title{
Pluralities in Feminist Geography: an interview with Robyn Longhurst
}

\author{
Rodrigo Rossi \\ GETE - State University of Ponta Grossa - Brazil
}

Feminist geographies and geographies of sexualities occupy academic spaces that are notable for being open to thematic plurality. This phenomenon has been seen in many of the careers of researchers in this sub-field of human geography. One such geographer is Robyn Longhurst who is from New Zealand. Her scientific production in the field of feminist geographies and geographies of sexualities represents an important contribution to contemporary human geography in the context of the relationship between body, gender, space and place and the critique of the masculinist epistemology and ontology of geography.

We interviewed this feminist geographer, who, along with editors and readers of the Revista Latino Americana de Geografia e Gênero (Latin American Journal of Geography and Gender) draws on concepts, ideas and experiences that are situated in a geography that is poststructuralist, based on Queer theory, and which is 'Down Under'. Longhurst's research is very varied and currently involves issues such as emotional and affective geographies, space, love, motherhood and information and communication technologies, the bodies of pregnant women, obesity, as well as cooking and food in the context of migrant women.

Longhurst's career also reflects a significant contribution to theoretical/ epistemological debates about feminism and geography, sexual violence, pregnant women and public space, the body, the home, masculinities, spaces of abjection, and sexual difference. It is a trajectory which, as well as revealing a wide range of possibilities for research in human geography, also shows a preference for a qualitative and critical methodology, which contributes to reflectivity in semi-structured, in-depth interviews, as well as in conducting focus groups.

Longhurst's active role on the Gender Commission of the International Geographical Union has also left indelible marks in relation to the emergence of feminist geographies and geographies of sexualities that are directed towards the global South.

Consequently, our interview was intended to be a dialogue about the main axes of Longhurst's academic output, as well as strategies of feminist geographies and geographies of sexualities in the transnational context.

Rodrigo Rossi: Your academic career is characterised by a plurality of themes developed in the field of feminist geographies and geographies of sexualities. Your position seems to have been linked with feminist geographies since your master's thesis on space and violence against women in 1985, and subsequently in your doctoral dissertation concerning public spaces and pregnant bodies in 1997. Your studies are aimed at understanding the relationship between bodies and spaces, incorporating an approach to sexuality that is linked with Queer theory. How are the major political/academic debates within feminist geographies and geographies of sexualities connected to your own intellectual trajectory within human geography?

Robyn Longhurst - For me, human geography, even when I was a Masters student in the mid-1980s, has never just been about humans per se but about people who are men, women, trans, straight, gay, lesbian, 
bi and so on. I remember in the 1980 s reading Moira Gatens' (1983) "A Critique of the Sex/Gender Distinction" in which she argues that bodies aren't neutral, rather "there are at least two kinds of bodies, the male body and the female body ... The subject is always a sexed subject" ( $p$ 145) and this really resonated with me. I had often reflected on how it seemed impossible to separate out sex and gender and how sex and gender often don't align, for example, men aren't always masculine, women aren't always feminine. Gatens' scholarship - along with that of other feminist theorists such as Elizabeth Grosz, Vicki Kirby, Iris Marion Young and Elspeth Probyn - inspired me to think about geography, space and place in new ways. Their ideas helped me understand issues like violence against women and pregnant bodies which you mention in your question and to explore them within a geographical framework. At the time I think my supervisors probably thought that sexual violence, and then a few years later pregnancy, weren't really appropriate topics for geographical research but I was determined. In my mind violence again women, and pregnancy, were just as relevant, if not more so than many other topics I could have chosen. They also spoke to my personal experiences. I wanted to research something that connected to my life.

R.R: In 2011, at the First Latin American Seminar of Geography and Gender in Rio de Janeiro, Brazil, you gave a presentation on the relationship between space and the experiences of single mother students in Aotearoa (New Zealand), using Gillian Rose's (1993) concept of paradoxical space. This concept is widely used today in the field of feminist geography in Brazil. In your view, is the concept of paradoxical space still useful in relation to the understanding of the relationship between space and gender and sexualities?

R.L. - I think Gillian Rose made a huge contribution with her 1993 book Feminism and Geography. She pushed arguments about the need to destablise dualisms such as Same and Other further than any other feminist geographers had. She also encouraged feminist geographers to take up a range of different strategies for critiquing geography's masculinism. Since the book's publication many others, myself included, have been inspired to take up the idea that space is paradoxical, or ambiguous, or constitututed by assemblages or how ever one choses to highlight the contradictory, overlapping and complex nature of space. I think, in short, the answer to your question is 'yes'. The concept of paradoxical space is still useful for understanding the relationship between space, gender and sexualities. Dualistic thinking hasn't disappeared. We still need to critique distinctions that are often drawn between culture/nature, production/reproduction, work/home, western/oriental and man/woman, for example. The discipline of geography is still masculinist. Gillian Rose argues using the notion of a politics of paradoxical space that feminism needs to occupy both the centre and the margin. It needs to be mobile, contradictory, and multiple in order to threaten the dualistic structure which has long dominated the geographical imagination. I agree with her. So, yes, I think the concept of paradoxical space is still relevant and it's good to hear that feminist geographers in Brazil are making effective use of the concept.

R.R. - You have written individually, or in partnership with other geographers, texts directed at understanding the experiences of men, masculine places and 
identities, and masculinities and their relationship with geography (LONGHURST, 2000; MORIN, LONGHURST and JOHNSTON, 2001; BERG and LONGHURST, 2003). Studies on masculinities emerged during the $1990 \mathrm{~s}$. In this context, feminism absorbed poststructuralist theories more strongly. However, studies of masculinities in geography have become underrepresented in conferences and seminars related to feminist geographies and geographies of sexualities. In your opinion, what contributions can result from the development of research on men, masculinities and masculine identities?

R.L. - I think it is hugely important for geographers who are interested in sex and gender to focus not just on women, femininities and feminine identities but also on men, masculinities and masculine identities and the relationship between these. In the early 1980s the focus was understandably on women and their lived experiences because women had been excluded and it was vitally important to 'put their stories on the agenda'. In more recent years though it has become evident that we also need to think about men, both in relation to women and in their own right. We need to examine those who occupy normative or hegemonic identities not just those who've been Othered or marginalized. So, for example, in studies of sexuality it is now more common to problematize and challenge normative - straight - sexualities. In studies of race and ethnicity people are examining 'whiteness'. In feminist studies the focus has shifted from examining women to also consider men. In order to destabilize patriarchal power relations it is necessary to examine not just femininity but also masculinity and the relationship between these constructs
R.R. - Your book, Bodies: Exploring Fluid Boundaries (2001) reveals a long and interesting process of social research and reflections on the material, subjective and fluid dimensions of the body, and how the body is potentially subversive, abject or marginalised when it is feminised, effeminate or dissonant in different spaces. Your writing, and that of Johnston (LONGHURST, HO \& JOHNSTON 2008; JOHNSTON \& LONGHURST 2010), suggest that the body is an instrument of research and that the possibilities of operationalising this methodological aspect reveal the development of an approach towards the body in geography. We would like

R.L. - Focusing on the body and all its messy materiality, has been a long-standing interest of mine. As you note I focus on this in the book Bodies and Lynda and I pick up this theme again in our book Space, Place and Sex and in our article on 'Using the body as an instrument of research' when we used cooking and eating with migrant women in Hamilton, New Zealand as a research methodology. Your question about what geographical imagination might emerge from this work on bodies as material and potentially abject is interesting and one that Lynda and I have been thinking about lately as we have been preparing an article that reflects on 21 years of work on 'the body' published in the journal Gender, Place and Culture since it began in 1994. We argue that in the past the mere mention of bodies, especially their messy materiality made some geographers squemish, to put it mildly! (LONGHURST \& JOHNSTON forthcoming). Nowdays bodies are discussed much more frequently, and within a wider variety of frameworks including nonrepresentational theory, performative geographies, and geographies of emotion and 
affect and so things have changed. Bodies are now on the agenda for many social, cultural, psychoanalytic, anti-racist, queer and feminist geographers. So I guess you could say that at last they are part of a particular geographical imagination, but in many places, and in some sub-disciplines there are still limits on these discussions. For example, it might be acceptable to write about emotion and affect, performativity, and the unconscious but not necessarily about menstrual blood, incontinence, or other bodily fluids that are part of daily life. In some ways then, 'real' fleshy bodies whether it be of the researcher or the researched are still too everyday, too material, too feminised - too Other maybe for geography.

R.R. - Your book, Space, Place and Sex: Geographies of sexualities, written with Lynda Johnston and published in 2010, represents an important step in human geography in the fight against homophobia. What kind of impact have the geographical perspectives of sexualities, the body, space and place, which are present in the book, had in the social sciences and in the feminist and LGBT movements?

R.L. - It's always difficult to know what affect one's work may or may not have on different individuals and communities. With Space, Place and Sex Lynda and I tried write it in a way that would make it accessible to a wide audience. We hoped that people inside, but also outside, the academy might read it. We are not sure how much this has happened but not long after the book was published we were invited to appear on Television New Zealand's Breakfast Show. This was a bit daunting - a live interview before breakfast! It, however, gave us a chance to communicate with a wide and diverse audience about the role of place in shaping sexuality which is not something that a lot of people necessarily think about. Responses to the interview were very positive.

R.R. - Many researchers in the fields of feminist geographies and geographies of sexualities are faced with an absence of theoretical studies and experiences of previous research with which to dialogue. Some of your studies were pioneering and uncommon in terms of geographical production, such as the relationship between space and the bodies of pregnant women (2005), obesity (2005), rural eroticism (JOHNSTON \& LONGHURST, 2010) and the cooking at home (JOHNSTON \& LONGHURST, 2013a \& 2013b). What are the main challenges and lessons that production within such poorly explored aspects of geographical science can provide?

R.L. - Many of the topics I've explored over the years have been considered by some to be unworthy of academic attention, that is, not 'proper' or 'serious' topics. This means that at times I have faced a few challenges such as snide comments made behind my back. Other times I have been confronted more directly with questions such as 'but what has that got to do with geography?' Addressing subject areas that have long been ignored, though, has also opened up opportunities to create new knowledges and spaces of critique. As I argue in Bodies the micro-level politics that imbue bodies are just as important as the macro-level politics that imbue nation states. What counts as legitimate knowledge within geography is complex and worth examining. It matters what knowledge is being produced. It also matters who is producing it and where it's produced. These are the kinds of issues that I wanted to raise in chosing topics such as pregnancy, obesity and cooking at home. 
R.R. - Some of your recent studies involve the problematisation of the virtual environment and cyberspace. What are the potential for information and communication technologies such as YouTube (2009) and Skype (2013), as sources of research and reflection in feminist geographies and geographies of sexualities?

R.L. - Yes, I have been working on issues of sex, gender, bodies and information communication technologies lately. It seems to me that increasingly we live simultaneously in off-line and on-line spaces that are deeply enmeshed and so it is important to understand the implications of this. I think there is potential for geographers interesed in media and communication, and geographers interested in sex and gender to work more closely. I am currently writing an article based on the experiences of 35 mothers who live in Hamilton, New Zealand who use digital communication technologies to connect with their children. I'm exploring the capacities of different technologies, both individually and combined, to prompt different emotions and affects. The article concludes that digital communication technologies aren't just cold, rational and removed from visceral experiences but rather intersect with emotion and affect. I am also currently writing a book about Skype. I am fascinated by how real-time audio-video calls which provide strong visual cues such as facial expressions, gestures, tone of voice and pauses, as well as where one is located, might be able to create feelings of 'presence'. The book focuses on how Skype is transforming social, cultural, sexual and gendered relations.

R.R. - What is the importance of your experience working in the Gender Commission of the International Geographical Union for your intellectual trajectory, as a feminist and as a supporter of Queer theory? Could you briefly assess the stage of development and dissemination of feminist geographies and geographies of sexualities in the world?

R.L. - I've loved being involved with the IGU Gender and Geography Commission over the past decade. It's a group of approximately 600 geographers from approximately 60 countries. As you know, because Brazil has been, and continues to be, involved with the Commission, including hosting an important meeting in Rio de Janeiro in 2011. We organise events each year and we connect via a newsletter that's sent out on e-mail by Professor Janice Monk. Your question about the stage of development and dissemination of feminist geographiesa nd sexualities in the world is an excellent one which I'll do my best to answer. The largest number of Gender and Geography listserv subscribers are in the US, UK and India where participation has grown rapidly over the past couple of years. The Commission also has members in Spain, Canada, Australia, Italy, Switzerland and my own country, New Zealand. We have a few subscribers, but not many, in western Europe, mainly Belgium, Germany, Austria and France. Unfortunately, though, we still don't have many on our list from east and southeast Asia, other than in Japan which hosted a meeting in 2013. Participation is also limited from African countries and from eastern Europe, although in 2009 we meet in Hungary and Romania and this generated some interest. We don't have a lot of subscribers from the Middle East, although we do have a few active participants from Israel. In Latin America membership is limited to Argentina, Mexico and Brazil. Actually, over the past few years we have seen some real growth in the number of subscribers from Brazil which is fantastic. I 
guess this is not surprising given the birth of Revista Latino Americana de Geografia e Gênero and the publication of a number of edited collections on the themes of gender and sexuality. It's good to see.

Maria Dolors Garcia Ramon and Janice Monk's (2007) special issue of Belgeo on 'Feminist Geographies around the World' is a useful source of information for anyone wanting to know more about the dissemination of feminist geography globally. Janice Monk's earlier article (1994) is also helpful. All in all, it seems geographers have made some very real progress in the areas of gender and sexuality but there is still a long way to go!

\section{References}

BERG, Lawrence; LONGHURST, Robyn. Placing Masculinities and Geographies, Gender, Place and Culture: A Journal of Feminist Geography, v. 10, n. 4, p. 351-360, 2003.

GARCIA RAMON, Maria Dolores; MONK, Janice. Feminist Geographies around the World (guest edited special issue of Belgeo) 2007.

GATENS, Moira. A Critique of the Sex/Gender Distinction. In: ALLEN, Judith; PATTON, Paul (Eds.) Beyond Marxism: Interventions after Marx. Leichhardt: Intervention Publication, 1983, p. 143 - 160.

JOHNSTON, Lynda.; LONGHURST, Robyn. Space, place and sex: Geographies of sexualities. Lanham - Maryland: Rowman \& Littlefield Publishers Inc, 2010.

JOHNSTON, Lynda; LONGHURST, Robyn. Trans(itional) geographies: bodies, binaries, places and space (translated into Portuguese), In:SILVA, Joseli Maria; ORNAT, Marcio Jose; CHIMIN JUNIOR, Alides Baptista
(Eds.). Geografias Malditas: corpos, sexualidades e espaço. Ponta Grossa: Todapalavra, 2013a, p. 339 - 355p.

JOHNSTON, Lynda; LONGHURST, Robyn. Mixed feelings: migrant women's experiences of food, eating and home in Hamilton, Aotearoa New Zealand. Hagar: Studies in Culture, Polities and Identities, v. 11, n. 1, p. $20-40,2013$ b.

LONGHURST, Robyn: Feminist perspectives on home. In: SMITH, Susan (Ed.). International Encyclopaedia of Housing and Home. Elsevier: Oxford, 2012, p. 158 162.

LONGHURST, Robyn; HODGETTS, Darrin; STOLTE, Ottilie. Mães solteiras que estudam em Aotearoa, Nova Zelândia: Uma política de espaço paradoxal. In: SILVA, Joseli Maria; SILVA, Augusto Cesar Pinheiro da (Eds.) Espaço, gênero e poder: conectando fronteiras. Ponta Grossa: Todapalavra, 2011, p.171- 184 .

LONGHURST, Robyn. Bodies: Exploring Fluid Boundaries, London: Routledge, 2001.

LONGHURST, Robyn. Breaking corporeal boundaries: pregnant bodies in public places. In: HOLLIDAY, Ruth; HASSARD, John (Eds.) Contested Bodies. London: Routledge, 2001, p. $81-94$.

LONGHURST, Robyn. Stretching mothering: gender, space and information communication technologies. Hagar: Studies in Culture, Polities and Identities, v. 11, n. 1, p. 121-138, 2013.

LONGHURST, Robyn. Using Skype to mother: bodies, emotions, visuality and screens, Environment and Planning D: Society and Space, v. 31, n. 4, p. $664-679$, 2013. 
LONGHURST, Robyn. YouTube: a new space for birth?. Feminist Review, v. 93, p 46-63, 2009.

LONGHURST, Robyn; HO, Elsie; JOHNSTON, Lynda. Using the body as an instrument of research: kimch'i and pavlova. Area, v. 40, n. 2, p. 208-217, 2008.

LONGHURST, Robyn. '(Ad)dressing Pregnant Bodies: Fashion, Clothing and Subjectivities'. Gender, Place and Culture: A Journal of Feminist Geography, v. 12, n. 4, p. 433-446, 2005.

LONGHURST, Robyn. Fat Bodies: Developing geographical research agendas. Progress in Human Geography, v. 29, n. 3, p. 247-259, 2005.

LONGHURST, Robyn. Geography and gender: masculinities, male identity and men. Progress in Human Geography, v. 24, n. 3, p. 439-444, 2000.

LONGHURST, Robyn; JOHNSTON, Lynda. Bodies, Gender, Place and Culture: 21 years on, Gender, Place and Culture, forthcoming.

MONK, Janice. Place matters: Comparative International Perspectives on Feminist Geography. The Professional Geographer, v. 46, n. 3, p. 277 - 288, 1994.

MORIN, Karin; LONGHURST, Robyn;JOHNSTON, Lynda. (Troubling) spaces of mountains and men: New Zealand's Mount Cook and the Hermitage Lodge. Social and Cultural Geography, v. 2, n. 2, p. 117-139, 2001.

ROSE, Gillian. Feminism \& Geography. The limits of Geographical Knowledge. Cambridge: Polity Press, 1993. 